\title{
Coloring mechanisms of ancient buried wood: Japanese cedar trees excavated from the foothills of Mt. Chokai
}

\author{
Yasuji Kurimoto ${ }^{1}$, Shigeru Yamauchi ${ }^{1 *}$, Tsutomu Takayama ${ }^{2}$ and Yoichi Sakai ${ }^{2}$
}

\begin{abstract}
Spectroscopic characterization of ancient buried Japanese cedar (Cryptomeria japonica) woods excavated from the foothills of Mt. Chokai was carried out to investigate the factors governing their color tones. X-ray fluorescence analysis confirmed primary metal elements in the Japanese cedar wood to be Ca and Fe. Infrared photoacoustic spectroscopy revealed that prolonged burial had not caused severe chemical decomposition of the ancient wood. ${ }^{57} \mathrm{Fe}$ Mössbauer spectra of the ancient wood samples suggested that Fe in the Japanese cedar wood was present in the high-spin $\mathrm{Fe}^{3+}$ or low-spin $\mathrm{Fe}^{2+}$ state. Although the dark color tone of the ancient wood has been assumed to be due to the presence of multinuclear Fe complexes with multidentate ligands such as tannin, no positive correlation was observed between the color depth and Fe content of the ancient wood samples.
\end{abstract}

Keywords: Ancient buried wood, Color tone, Mössbauer spectroscopy, Raman spectroscopy, Iron, Japanese cedar

\section{Introduction}

Umoregi and jindai-boku are typical Japanese terms that refer to ancient trees buried or submerged as a result of natural phenomena (e.g., landslides, debris, avalanches, and ground subsidence) more than several centuries ago. These terms are generally applied to the ancient trees that have not been substantially denatured in terms of their physical properties and main constituents. Since, up to the point of their excavation, ancient buried trees have been shielded from sunlight and air, most of them have not suffered severe damage if their burial period time was within several 1000 years. In English, the terms bog wood, fossil wood (or sub-fossil wood), lignite, etc. have been utilized as translations of umoregi and jindaiboku; however, the meaning of these English terms is not exactly equivalent to that of the mentioned Japanese terms. A scientific definition for the wood identified by these Japanese words does not yet exist. Thus, we here

\footnotetext{
*Correspondence: sigeru@iwt.akita-pu.ac.jp

${ }^{1}$ Institute of Wood Technology, Akita Prefectural University, 11-1

Kaieisaka, Noshiro 016-0876, Japan

Full list of author information is available at the end of the article
}

use the term of umoregi and define as "umoregi wood" the stem of an ancient buried tree that contains neither carbonized nor petrified components. We call the stem of present-day trees "modern wood".

In general, umoregi wood turns dark or deep color, so that this wood is treated as a premium woody material for the manufacture of various products, especially furniture, owing to its color tone. Although not so often, umoregi wood is even used as construction materials.

Based on studies of iron-gall ink [1-6] and timber color changes associated with Fe contamination $[7,8]$, the idea that the iron complexes with tannin lead to the characteristic umoregi-wood color has been long accepted. Nevertheless, there has been no study that had focused on the coloring mechanism of umoregi wood prior to our previous work [9], even though Mössbauer spectra of Fe in umoregi wood have been already reported [10, 11]. In our previous report [9], we comprehensively analyzed umoregi wood from Japanese cedar (Cryptomeria japonica) and from three other tree species using Mössbauer and supplementary spectroscopic techniques, and discussed the chemical states of Fe complexes bringing about the coloring of umoregi wood. However, further
Springer Open (c) The Author(s) 2020. This article is licensed under a Creative Commons Attribution 4.0 International License, which permits use, sharing, adaptation, distribution and reproduction in any medium or format, as long as you give appropriate credit to the original author(s) and the source, provide a link to the Creative Commons licence, and indicate if changes were made. The images or other third party material in this article are included in the article's Creative Commons licence, unless indicated otherwise in a credit line to the material. If material is not included in the article's Creative Commons licence and your intended use is not permitted by statutory regulation or exceeds the permitted use, you will need to obtain permission directly from the copyright holder. To view a copy of this licence, visit http://creativeco mmons.org/licenses/by/4.0/. 
investigations were required to elucidate more clearly the mechanism by which umoregi wood samples acquire their colors.

We previously studied the coloring mechanisms of umoregi wood and its ash for the four kinds of trees [9, 12]. In this study, our attention was focused on the differences in color tone among the umoregi wood samples of the same tree species and among the parts of an umoregi tree. As for most of the Japanese cedar umoregi trees, the sapwood showed much more lightly color tones compared with the heartwood. Thus, we selected two Japanese cedar umoregi trees of which heartwood displayed different colors from each other, and they were characterized using ${ }^{57} \mathrm{Fe}$ Mössbauer spectroscopy and several other analytical techniques. The aim of the present study is to achieve a deeper understanding of the coloring mechanisms of umoregi wood.

\section{Experimental}

\section{Japanese cedar umoregi trees}

The Japanese cedar umoregi trees used in this study were dug up in 2018 from Nikaho City in Akita Prefecture, Japan, in a location to the north-west of Mt. Chokai. The excavation point was located at $39^{\circ} 13^{\prime} 44^{\prime \prime}$ north latitude and $139^{\circ} 58^{\prime} 4^{\prime \prime}$ east longitude. The umoregi trees were probably buried by the heavy landslides occurring around the north-west foothills of Mt. Chokai about 2500 years ago [13].

\section{Umoregi wood}

The log of umoregi wood was cut into small blocks after air-drying in door for several months. Umoregi wood blocks were then ground to powder, which could be made to pass through a 40-mesh sieve, using a cutting mill. The umoregi wood powder samples obtained were submitted for the spectrometric measurements.

\section{Bleaching with oxalic acid}

The umoregi wood blocks were cut into smaller blocks $\left(15 \times 15 \times 15 \mathrm{~mm}^{3}\right)$ and dried at $105{ }^{\circ} \mathrm{C}$ for $24 \mathrm{~h}$ in an electric oven. These dried blocks were immersed in aqueous oxalic acid solution ( $3 \mathrm{w} / \mathrm{w} \%)$ of special-grade oxalic acid purchased from Fujifirm Wako Pure Chemical, Corp., and then a glass beaker holding the solution and blocks was placed in a vacuum desiccator. The blocks were kept at room temperature for $15 \mathrm{~min}$ in the desiccator, inside which the pressure was sufficiently reduced using a water-jet pump. They were taken out from the solution and dried in air for 2 days.

\section{X-ray fluorescence spectrometry}

The content of elements from $\mathrm{Mg}$ to $\mathrm{Sr}$ present in the Japanese cedar umoregi wood was determined by X-ray fluorescence (XRF) spectrometry using a compact spectrometer (MESA-500, Horiba, Ltd., Japan). Umoregi wood powder samples $(\sim 0.12 \mathrm{~g})$ were placed in a cylindrical polytetrafluoroethylene (Teflon) cell with a diameter of $20 \mathrm{~mm}$. The sample chamber of the compact spectrometer was evacuated using an oil-sealed rotary vacuum pump during measurements. X-ray irradiation was performed at room temperature for a total measurement time of $2000 \mathrm{~s}$. The X-ray tube voltages were $15 \mathrm{kV}$ $(1000 \mathrm{~s})$ and $50 \mathrm{kV}(1000 \mathrm{~s})$. Relative mass percentages of elements to total elements detected were estimated using a standardless fundamental parameter method [14, 15] from characteristic X-ray intensities.

\section{Infrared photoacoustic spectroscopy}

Infrared photoacoustic (IR-PA) spectra were recorded at room temperature using a spectrometer (JIR7000W, Jeol, Ltd., Japan) connected with an IR-PA spectroscopy module (IR-PAS 1000, Jeol, Ltd., Japan). The spectra were obtained from 300 accumulations with a spectral resolution of about $4 \mathrm{~cm}^{-1}$. A thin cell (diameter, $5 \mathrm{~mm}$ ) was filled with the wood powder, and photoacoustic signals were collected upon, flowing helium gas $(10 \mathrm{~mL} / \mathrm{min})$ through a cell bench. The moving-mirror velocity was fixed at $1.6 \mathrm{~mm} / \mathrm{s}$. Amorphous carbon was used as a reference.

\section{Mössbauer spectroscopy}

${ }^{57} \mathrm{Fe}$ Mössbauer spectra were recorded using a Mössbauer spectrometer (Model-222, Topologic System Inc., Japan) with a ${ }^{57} \mathrm{Co}(\mathrm{Rh})$ source $(925 \mathrm{MBq})$ in an ordinary transmission mode. Measurement temperatures were $298 \mathrm{~K}$ and $78 \mathrm{~K}$, and they were regulated using an Oxford cryostat DN-1726 with a temperature controller of ITC601 . On the assumption that all spectra were composed of Lorentzian-shaped peaks, curve fitting of the Mössbauer spectra was performed by a nonlinear least-squares method using the MossWinn 4.0Pre. program. The isomer shift $(I S)$ values and Doppler velocity scale were calibrated with respect to a set of sextet due to $\alpha$-Fe at room temperature.

The thicknesses of Japanese cedar umoregi wood samples were in the $64-70 \mathrm{mg} / \mathrm{cm}^{2}$, and these allowed us to discuss Mössbauer absorption intensities semi-quantitatively.

\section{Results and discussion}

Color tone of Japanese cedar umoregi woods and bleaching with oxalic acid

Figure 1 shows photos of two Japanese cedar umoregi wood samples characterized in this study. These samples $\mathrm{a}$ and $\mathrm{b}$ were obtained from the different individuals of Japanese cedar. As shown in Fig. 1, the sample a 


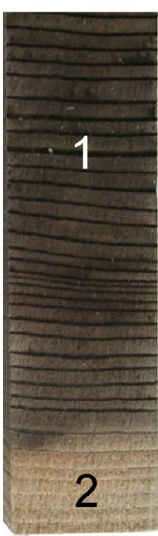

a

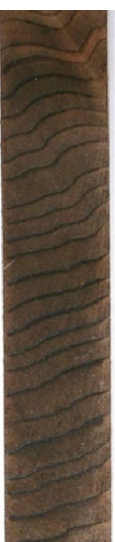

b

Fig. 1 Photographs of the cross-section of three parts in two Japanese cedar umoregi wood samples for (a-1) UW1-1, (a-2) UW1-2, and (b) UW2. UW1-1: heartwood, UW1-2: sapwood, UW2: heartwood

(umoregi wood 1: UW1) contains both heartwood and sapwood parts, which, much like modern wood, are distinguishable from each other by entirely different color tones. The heartwood and sapwood sections of this sample are abbreviated as UW1-1 and UW1-2, respectively. Although the sample b (umoregi wood 2: UW2) most likely contains only heartwood, UW2 displays a slightly lighter and reddish-brown color as compared with UW1-1.

Figure 2 demonstrates the changes of the color tone resulting from oxalic acid treatment. The three parts (a1,

A
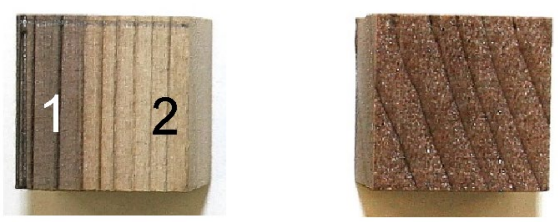

B

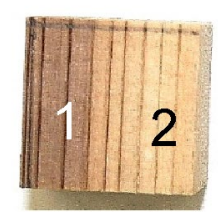

a

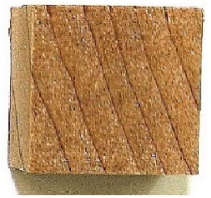

b
Fig. 2 Photographs of three parts in two Japanese cedar umoregi wood samples before and after treatment with oxalic acid solution. A Samples before treatment; (a-1) UW1-1, (a-2) UW1-2, and (b) UW2. B Samples after treatment; (a-1) UW1-1, (a-2) UW1-2, and (b) UW2. UW1-1: heartwood, UW1-2: sapwood, UW2: heartwood $\mathrm{a} 2$ and $\mathrm{b}$ ) in the two samples before the treatment in the top row (A) of the figure show their original dark tones. As is evident from the photos in the bottom row (B) after the treatment, the three umoregi wood parts have the appearance of modern wood, as a result of the loss of their characteristic colors following the immersion into oxalic acid solution and subsequent drying. Thus, most of Fe in the umoregi wood are probably treated by oxalic acid chemically.

\section{IR-PA spectra of Japanese cedar umoregi wood}

Figure 3 depicts IR-PA spectra over a $2000-800 \mathrm{~cm}^{-1}$ range, where the top spectrum (a) is for the modern wood and the other three ones (b, $c$ and $d$ ) are for umoregi wood samples. The three IR-PA spectral line-shapes of umoregi wood samples are extremely similar to one another as seen in Fig. 3b-d. No significant differences were observed between the umoregi and modern wood with respect to the vibrational bands attributed to phenyl groups of lignin $\left(\sim 1590 \mathrm{~cm}^{-1}\right.$ and $\left.\sim 1500 \mathrm{~cm}^{-1}\right)$ [16, $17]$ and to saturated cyclic groups of cellulose or hemicellulose (1450-1320 $\mathrm{cm}^{-1}$ and $1180-1000 \mathrm{~cm}^{-1}$ ) [16]. A remarkable difference between the spectra of the modern and umoregi wood samples is found around $1740 \mathrm{~cm}^{-1}$; the relative intensity of the band for umoregi wood is much weaker than that of the modern wood. This band is attributed mainly to $\mathrm{C}=\mathrm{O}$ stretching vibrations in carboxy [16] and/or unconjugated carbonyl [18] groups. In

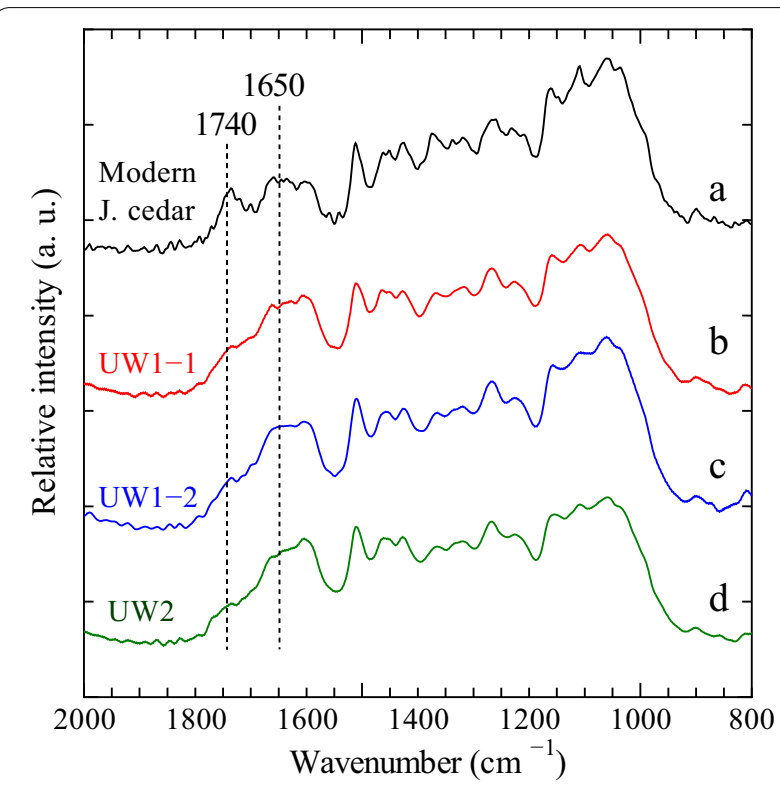

Fig. 3 Infrared photoacoustic spectra in the $2000-800 \mathrm{~cm}^{-1}$ region for (a) modern Japanese cedar (heartwood, black solid line), (b) UW1-1 (heartwood, red solid line), (c) UW1-2 (sapwood, blue solid line), and (d) UW2 (heartwood, green solid line) 
addition, the stretching vibrations in conjugated $\mathrm{C}=\mathrm{O}$ groups generate a band at $\sim 1650 \mathrm{~cm}^{-1}$ [18], and the band intensity seems to be somewhat weaker for the umoregi wood than for the modern wood. Thus, the IR-PA spectra of the umoregi wood samples indicate that some chemical changes have occurred in the carboxy and/or carbonyl groups during the 2500-year burial. It is, however, likely that the overall chemical degradation rate had been substantially decreased for the Japanese cedar umoregi wood investigated here.

\section{Elements in umoregi wood}

Table 1 summarizes the relative mass percentage of elements from $\mathrm{Mg}$ to $\mathrm{Sr}$ in the umoregi wood samples determined here by XRF spectrometry.

Tsuchiya et al. measured the minor element contents in the wood and bark of many kinds of modern tree species including Japanese cedar using inductively coupled plasma emission spectrometry [19]. They reported that Ca was a primary or secondary element among metals, exceeding $800 \mathrm{mg} / \mathrm{kg}$ in the modern Japanese cedar wood samples, while Fe was undetectable or a trace element $(<10 \mathrm{mg} / \mathrm{kg})$ and less abundant than Al.

The umoregi wood has not severely deteriorated as mentioned above, and therefore $\mathrm{C}, \mathrm{O}$, and $\mathrm{H}$ should be major elements as well as the wood of modern tree. However, as is evident from Table 1, Fe is a primary

Table 1 Relative mass percentages of elements, tentative true mass percentages of $\mathrm{Fe}$, and ash contents in Japanese cedar umoregi wood samples

\begin{tabular}{lccc}
\hline Sample & UW1-1 & UW1-2 & UW2 \\
\hline Cash $_{2}$ & 0.57 & 0.76 & 0.91 \\
$\mathrm{TM}_{\mathrm{Fe}}$ & 0.33 & 0.41 & 0.26 \\
$\mathrm{Mg}$ & 1.9 & 3.5 & 1.3 \\
$\mathrm{Al}$ & 1.7 & 1.5 & 2.1 \\
$\mathrm{Si}$ & 7.8 & 6.2 & 8.1 \\
$\mathrm{~S}$ & 1.3 & 8.2 & 0.8 \\
$\mathrm{~K}$ & 0.9 & 0.9 & 1.6 \\
$\mathrm{Ca}$ & 27.1 & 24.5 & 56.7 \\
$\mathrm{Ti}$ & 0.3 & 0.3 & 0.4 \\
$\mathrm{Cr}$ & 0.1 & 0.1 & 0.1 \\
$\mathrm{Mn}$ & 0.7 & 0.6 & 0.1 \\
$\mathrm{Fe}$ & 57.5 & 53.6 & 28.0 \\
$\mathrm{Ni}$ & 0.3 & 0.3 & 0.4 \\
$\mathrm{Cu}$ & 0.1 & 0.1 & 0.0 \\
$\mathrm{As}$ & 0.1 & & 0.1 \\
$\mathrm{Sr}$ & 0.2 & 0.1 & 0.2 \\
\hline
\end{tabular}

Blank space implies "not detected"

$\mathrm{C}_{\text {ash }}$ is ash content of umoregi wood

$T M_{\mathrm{Fe}}$ is a tentative true mass percentage of $\mathrm{Fe}$ or secondary element in all the Japanese cedar umoregi wood samples. The large $\mathrm{Fe}$ contents suggest that Fe was slowly transferred from the soil to the umoregi wood during the prolonged burial period. Other transition metals, $\mathrm{Cr}, \mathrm{Mn}, \mathrm{Ni}$, and $\mathrm{Cu}$, that have the potential to change color of umoregi wood were also detected, and however, their relative mass percentages are much lower than those of Fe. Hence, the effects of these elements on the color tone of the umoregi wood are very likely to be negligible.

The main three elements of modern wood are $\mathrm{C}, \mathrm{O}$, and $\mathrm{H}$, and the sum of them is about $99 \%$ of the mass of modern wood. These elements and $\mathrm{N}$ are not detectable by ordinary XRF methods. Thus, the relative mass percentages listed in Table 1 should be estimated much larger than the true mass percentages, because the Japanese cedar umoregi wood samples have scarcely degraded as mentioned above. A simple calculation process was applied to approximate evaluation of the true mass percentage of Fe in the umoregi wood. In specific, the tentative true mass percentages of Fe were calculated using Eq. (1), on the assumption that $\mathrm{C}, \mathrm{O}, \mathrm{H}$, and $\mathrm{N}$ were completely emitted from wood into the air by burning, although trace amounts of $\mathrm{O}$ remain as various oxides in the ash

$$
T M_{\mathrm{Fe}}=R M_{\mathrm{Fe}} \times C_{\mathrm{ash}} \times 1 / 100
$$

where $T M_{\mathrm{Fe}}$ and $R M_{\mathrm{Fe}}$ are the tentative true and relative mass percentages of $\mathrm{Fe}$, respectively, and $C_{\text {ash }}$ the ash content of umoregi wood. As listed in Table 1, the $C_{\text {ash }}$ of UW1-1, UW1-2, and UW2 was $0.57 \%, 0.76 \%$, and $0.91 \%$, respectively. Thus, the $T M_{\mathrm{Fe}}$ calculated from Eq. (1) is in the order: UW1-2 $(0.41 \%)>$ UW1-1 $(0.33 \%)>$ UW2 $(0.25 \%)$. Meanwhile, the color depth of umoregi wood seems to be in the order: UW1-1 $\geq$ UW2 $>$ UW1-2, as shown in Fig. 1. Accordingly, the elemental analysis using XRF spectrometry leads to the conclusion that the color depth of umoregi wood does not necessarily increase with the Fe content, although it has been believed that the color depth might be dependent mainly upon $\mathrm{Fe}$ content.

\section{Mössbauer spectra of umoregi wood}

Figure 4 shows Mössbauer spectra of the umoregi wood samples recorded at $78 \mathrm{~K}$. A curve-fitting procedure was carried out, assuming that all the spectra were composed of only a set of Lorentzian doublet. Table 2 summarizes the Mössbauer parameters for the spectra at $78 \mathrm{~K}$ of the three samples of umoregi wood.

As listed in the table, the $I S$ and quadrupole splitting $(Q S)$ values of UW1-1 and UW1-2 were quite close to those we reported previously for the umoregi wood of various kinds of tree [9], whereas both the parameter 


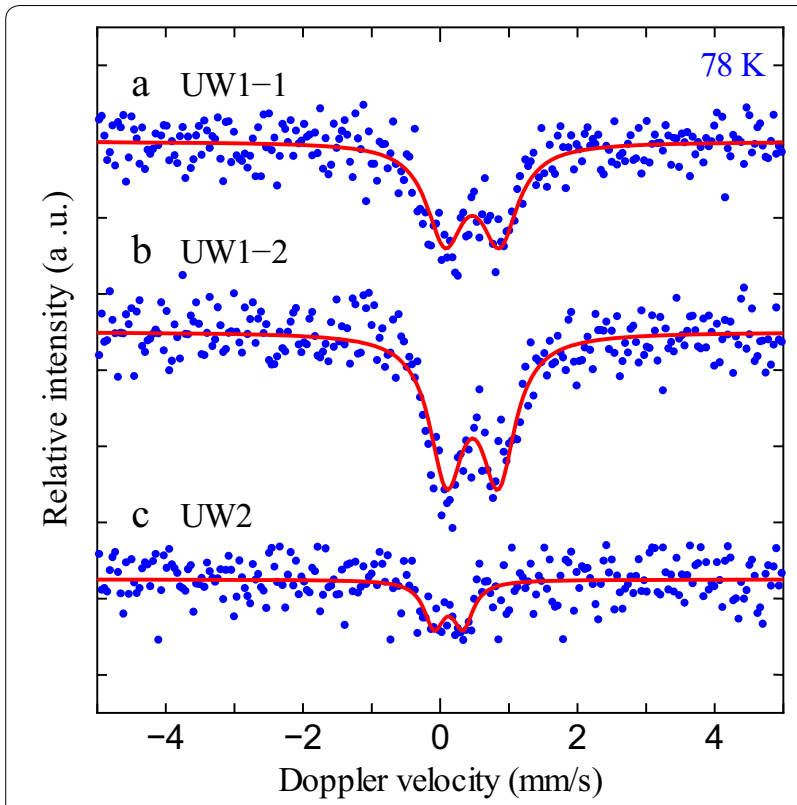

Fig. 4 Mössbauer spectra at $78 \mathrm{~K}$ of Japanese cedar umoregi wood. (a) UW1-1 (heartwood), (b) UW1-2 (sapwood), and (c) UW2 (heartwood). Red solid line is a fitting curve line

Table 2 Mössbauer parameters at $78 \mathrm{~K}$ of Japanese cedar umoregi wood samples

\begin{tabular}{llll}
\hline Sample & IS (mm/s) & QS ( $\mathbf{m m} / \mathbf{s})$ & LW $(\mathbf{m m} / \mathbf{s})$ \\
\hline UW1-1 & $0.47(2)$ & $0.80(3)$ & $0.65(6)$ \\
UW1-2 & $0.47(2)$ & $0.75(3)$ & $0.59(4)$ \\
UW2 & $0.12(3)$ & $0.42(5)$ & $0.35(9)$ \\
\hline
\end{tabular}

IS isomer shift; $Q S$ quadrupole splitting; $L W$ line width

values of UW2 were substantially smaller than those of UW1-1 and UW1-2. The Mössbauer spectra provide the following chemical information on $\mathrm{Fe}$ in the umoregi wood.

First, the $I S$ and $Q S$ values suggested that UW1-1 and UW1-2 probably contained Fe in the form of highspin $\mathrm{Fe}^{3+}$ complexes, by taking into account the Mössbauer parameters (IS and $Q S$ ) previously reported [20-22]. Moreover, the ligands of the complexes are likely to be polyphenols such as tannin having pyrogallol groups. However, there have been several problems to be solved for their molecular structure, for example, the coordination number of Fe.

Second, the $I S$ value at $78 \mathrm{~K}$ of UW2 is $0.12 \mathrm{~mm} / \mathrm{s}$, suggesting that Fe in UW2 is present in low-spin $\mathrm{Fe}^{2+}$ $[20,21]$ and has a six-coordination structure [22]. It is for the first time that low-spin $\mathrm{Fe}^{2+}$ was identified in umoregi wood. Our finding of low-spin $\mathrm{Fe}^{2+}$ in the umoregi trees excavated from the foothills of Mt. Chokai may provide a clue to clarify the transfer mechanism of Fe from soil to umoregi wood since Fe probably transfers as $\mathrm{Fe}^{2+}$ from soil to umoregi wood [9]. According to the previous studies on metal-gall complexes [1-6], low-spin $\mathrm{Fe}^{2+}$ in UW2 presumably forms complexes with polyphenols as well as high-spin $\mathrm{Fe}^{3+}$.

The factors determining the color of umoregi wood will be extremely complicated, and further study is required to confirm a causal relationship between the chemical state of $\mathrm{Fe}$ and the color tone of umoregi wood.

\section{Conclusion}

The present work provided an outcome that the brown color tones of Japanese cedar umoregi wood excavated from the foothills of Mt. Chokai are most likely due to the multinuclear complexes of Fe with polyphenol ligands having pyrogallol groups; however, the color tone depth is not necessarily proportional to the Fe concentration in umoregi wood. Moreover, the color tone of umoregi wood might be substantially dependent upon the chemical properties of Fe complexes with polyphenols.

The factors affecting the color of umoregi wood are very complicated. Additional studies on a wider range of umoregi wood samples are required to explain in detail the coloring mechanism of umoregi wood.

\section{Abbreviations \\ UW ( $\mathrm{X}$ in UWX is a sample number. $\mathrm{X}$ is 1-1, 1-2, or 2.): Japanese cedar umoregi wood; IR-PA: Infrared photoacoustic; IS: Isomer shift; QS: Quadrupole splitting; $L W$ : Line width; $T M_{\mathrm{Fe}}$ :Tentative true mass percentage of $\mathrm{Fe} ; R M_{\mathrm{Fe}}$ : Relative mass percentage of $\mathrm{Fe} ; \mathrm{C}_{\text {ash }}$ : Ash content in a percent unit.}

\section{Acknowledgements}

The authors are deeply grateful to the Liaison Council for the grant.

\section{Authors' contributions}

YK collected Japanese cedar umoregi trees and selected the umoregi wood samples appropriate for this study. YK and SY designed this study, and wrote the initial draft of the manuscript. YK and SY were in charge of IR-PA and X-ray fluorescence analyses. YS and TT were major contributors in obtaining and analyzing Mössbauer spectra. All authors have contributed to data collection and interpretation, and critically reviewed the manuscript. All authors read and approved the final manuscript.

\section{Funding}

Part of this study was supported by 2019 grant for research in Geoparks from Akita Prefecture Geopark Liaison Council.

\section{Availability of data and materials}

Not applicable.

\section{Competing interests}

The authors declare that they have no competing interests.

\section{Author details}

1 Institute of Wood Technology, Akita Prefectural University, 11-1 Kaieisaka, Noshiro 016-0876, Japan. ${ }^{2}$ Department of Chemistry, Daido University, Takiharu-Cho, Minami-ku, Nagoya 457-8530, Japan. 
Received: 24 January 2020 Accepted: 24 March 2020

Published online: 06 April 2020

\section{References}

1. Wunderlich CH, Weber R, Bergerhoff G (1991) Über Eisengallustinte. Z anorg allg Chem 598(599):371-376

2. Krekel C (1999) The chemistry of hysterical iron gall inks. Int J For Doc Exam 5:54-58

3. Wagner B, Bulska E, Stahl B, Heck M, Ortner HM (2004) Analysis of Fe valence states in iron-gall inks from XVIth century manuscripts by ${ }^{57} \mathrm{Fe}$ Mössbauer spectroscopy. Anal Chim Acta 527:195-201

4. Burgaud C, Rouchon V, Refait P, Wattiaux A (2008) Mössbauer spectrometry applied to the study of laboratory samples made of iron gall ink. Appl Phys A 92:257-262

5. Canevari C, Delorenzi M, Invernizzi C, Licchelli M, Malagodi M, Rovetta T, Weththimuni M (2016) Chemical characterization of wood samples colored with iron inks: insights into the ancient techniques of wood coloring. Wood Sci Technol 50:1057

6. Feller RK, Cheetham AK (2006) Fe(III), Mn(II), Co(II), and Ni(III) 3,4,5-trihydroxybenzonate (gallate) dihydrates; a new family of hybrid framework materials. Solid State Sci 8:1121-1125

7. Sandermann W, Lüthgens M (1953) Untersuchngen über Verfärbungen von Hölzern. Holz als Roh-u Wérkst 11:435-440

8. Takenami K (1964) Studies on the discoloration of wood. I. Sensitivities of various wood species for the dyeing effect with iron (in Japanese). Mokuzai Gakkaishi 10:22-29

9. Yamauchi S, Kurimoto Y, Sakai Y (2017) Mössbauer characterization of iron in ancient buried trees excavated from the foothills of Mt. Chokai. J Nucl Radiochem Sci 17:23-29

10. Yamauchi S, Sakai Y, Aimi H (2011) Iron speciation in iron-rich wood by Mössbauer spectroscopy. J Wood Sci 57:549-552

11. Bürck U, Wagner FE, Lerf A (2012) Mössbauer studies of subfossil oak. Hyperfine Interact 208:105-110
12. Yamauchi S, Kurimoto Y, Sakai Y (2017) Mössbauer spectroscopic characterization of iron in ashes made from the ancient woods excavated in the foothills of Mt. Chokai. J Nucl Radiochem Sci 17:1-7

13. Sakurai H, Kato W, Takahashi Y, Suzuki K, Takahashi Y, Gunji S, Tokanai F (2006) 14C dating of 2500-yr-old Choukai jindai cedar tree rings from Japan using highly accurate LSC measurement. Radiocarbon 48:401-408

14. Kira A, Robson N (2001) Versatile multi-element analysis using X-ray fluorescence. The MESA-500 series and the MDX-1000 series. Readout No. 22:19-25

15. Elam WT, Shen RB, Scruggs B, Nicolosi J (2004) Accuracy of standardless FP analysis of bulk and thin film samples using a new atomic database. Adv X-Ray Anal 47:104-109

16. Michell AJ, Watson AJ, Higgins HG (1965) An infrared spectroscopic study of delignification of Eucalyptus regnans. Tappi 48:520-532

17. Agarwal UM, MCSweeny JD, Ralph SA (2011) FT-Raman investigation of milled-wood lignins: softwood, hardwood, and chemically modified black spruce lignins. J Wood Chem Technol 31:324-344

18. Lewis IR, Daniel NW Jr, Chaffin NC, Griffiths PR (1994) Raman spectrometry and neural networks for the classification of wood types-1. Spectrochim Acta 50A:1943-1958

19. Tsuchiya Y, Shimogaki H, Abe H, Kagawa A (2010) Inorganic elements in typical Japanese trees for woody biomass fuel. J Wood Sci 56:53-63

20. Gütlich P, Bill E, Trautwein AX (2011) Mössbauer spectroscopy and transition metal chemistry_Fundamentals and applications. Springer-Verlag, Berlin

21. Greenwood NN, Gibb TC (1971) Mössbauer spectroscopy. Chapman and Hall Ltd., London

22. Vandenberghe RE, De Grave E (2013) Application of Mössbauer spectroscopy in earth sciences. In: Yoshida Y, Langouche G (eds) Mössbauer spectroscopy. Springer, Berlin, pp 91-185

\section{Publisher's Note}

Springer Nature remains neutral with regard to jurisdictional claims in published maps and institutional affiliations.

\section{Submit your manuscript to a SpringerOpen ${ }^{\circ}$ journal and benefit from:}

- Convenient online submission

- Rigorous peer review

- Open access: articles freely available online

- High visibility within the field

- Retaining the copyright to your article

Submit your next manuscript at springeropen.com 